\title{
カラー画像解析による頭髪つやの評価
}

\author{
前田哲夫 岡田正紀 渡辺 博 原烈

\section{Measurements of Hair Luster by Color Image Analysis}

\author{
Tetsuo Maeda, Masanori Okada, \\ Hiroshi Watanabe and Tadashi Hara
}

\begin{abstract}
Accurate measurements of hair luster on the head (HLH) in situ is not an easy task and no satisfactory method is available at this time.

A new instrumental analysis method called "Color Image Analysis" was developed in this study to overcome the problem. In this method, a ratio of mean brightness in the highlight and adjoining dark portion of the hair image is computed from blue and red color signals. The result was much improved correlation with visual observation, compared with formerly used goniophotometry, since our HLH data included elements of micro-surface condition, macro-state as well as color.

Using this method, effects of changes in the state of hair and usefullness of hair-care products were investigated. We obtained interesting results on the effects of hair-luster preparations and hair coloring. It was clear that our method could be used to accurately determine the difference in hair luster.
\end{abstract}

\section{1. 緒 言}

頭髪つや $(\mathrm{HLH})$ は，コーザーがヘアケア製品に望さ 大きなニーズの一つであり，へア研究者が製品の効果や 有用性を評価していく上での重要な髮特性とされてい る。日本人女性 119 名で行った我々の調查でも，自分そ して他人の頭髪の健康さを判断する時には, HLH を最 も重視してみているといら結果が示された。このよらに HLH は, ヘア研究者にとって重要な髪特性であるが, それを正確に測定することは容易ではない。

物質のつやの測定法には, 鏡面光沢, 対比光沢, 鮮明 度光沢を測定する等のいくつかの方法がある゙。このう ら頭髮のつや測定には, 頭髪から採取した単繊維毛の正 反射強度と拡散反射強度の対比值をゴニオフォトメータ 一で求める方法 ${ }^{2}$ （以下ゴニオフォメーター法）が一般 的に利用されてきた。

ポーラ化成工業(侏横浜研究所：横浜市神奈川区高島台 27-1

POLA Yokohama Laboratories: 27-1 Takashimadai Kanagawaku, Yokohama, Japan
ところが，頭髪は曲面を有する多数の繊維の集合体で めるため，単繊維毛の測定結果は必ずしも頭髪の真のつ やの状態を反映はしない。また視覚による物質つやの観 察は, highight 部とその周边の dark 部の比較で評価さ れると考光ら机てるが、ゴニオフォトメーターでこ のような測定はなし得ない。そのためゴニオフォトメー ターと視覚評価結果との不一致がしばしば発生する。し かしながら、ゴニオフォトメーター法に代替し得る視覚 と一致性の高いHLH 測定法は未だ見られないのが現状 である。

他方, 視覚に代替する種々の特性の測定方法として, ビデオカメラと画像処理装置を用い入力画像を解析する 測定法の開発が近年種々の分野で進められている。この 画像処理法は，現在主に物体や生体組織の形状あるいは パターン評価に広く利用されようとしている手法であ る。しふし HLH 測定への応用は未だみられない。

そこで今回，視覚と一致性の高いHLH の機器測定法 確立を目的として, カラー画像処理法の開発を試みた。 さらに, 本法を用いて HLH に影響する頭髪状態の変化 やへアケア製品の有用性についても検討したので報告す 
る。

\section{2. 方 法}

\section{1 Hair Sample}

毛束, model wig 和よびパネラー頭髪を用いた。毛 束は黒髪 $40 \mathrm{~g}, 30 \mathrm{~cm}$ を一束として用いた。パネラー は，つやの㥗又が多い年代である20歳代の健常日本女性 33名を用いた。今回は straight hair 者を中心に選び, irregular 岁るいは permanent waved hair 者は除外 した。

\section{2 視覚的つやの評価}

熟練した専門評価者 5 名で実施した。あらかじめ順位 配列法3)にて 5 段階の異なったつやのモデル毛束を準備 し，これとの比較で試料のつやを評価した。毛束はmodel wig の頭髪に固定して測定した。判定は, $25^{\circ} \mathrm{C}$, $50 \%$ 湿度下の暗室にて, 試料の $30^{\circ}$ 上万から True Light (20W DURO-TEST) の照明下で行なった。光源の位置 は，試料表面の照度が $250 \mathrm{Lux}$ となるようセットした。

\section{3 ゴニオフォトメーターによる物理的つやの測定}

視覚的つやを測定した試料の一部から単繊維毛を10 15本採取し，ゴニオフォトメーター（村上色彩研究所） を用いて，光源入射角 $30^{\circ}$ の条件でそれらの正反射值(s) と拡散反射值 (d) (reflection angle $=0^{\circ}$ ) を測定した。 そして s/d をゴニオフォトメーター值とした。

\section{4 カラー画像処理法による物理的つやの測定}

視覚的つやの測定後, 試料を, その $30^{\circ}$ 上方からの Standard A Luminant (100V 150W Kenko) 照明下に てビデオカィラ (Victor KY-1900) を用いて撮影した。 光源の位置は, 試料表面の照度が 1500Lux となるよう セットした。またビデオカメラは, 試料の後方 $160 \mathrm{~cm}$ の位置にセットした。

撮影した頭髪映像は, カラー画像処理装 置 (Nexus 6400)を用いて解析した。

Fig.-1 に画像解析システムの概略図を示す。

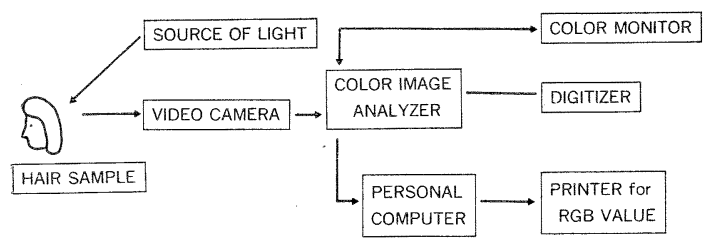

Fig.-1 Image Analysis System.

カラー画像処理装置により red, green, blue の 3 原 色信号 (以下 RGB 信号) に分解さ机た画像情報を種々 の方法で検討した。

\section{3. 結果および考察}

カラー画像処理装置により red, green, blue の 3 原 色信号に分解された画像情報の解析法にはいくつかの 方法がある ${ }^{42 \sim 6)}$ 。我々は，頭髪画像の解析法として，(1) $\mathrm{Y}$ 軸方向の輝度変化を解析する方法，(2)頭髧画像全体の 画素濃度ヒストグラムを解析する方法, (3)測定領域をカ ラーモニター画面上で設定しその領域の平均輝度を求め る方法等いくつかの方法について検討した。その結果, 測定領域をカラーモニター画面上で設定しその領域の情 報を解析する(3)の方法が種々の複雑な頭髮状態を一定方 法で最も簡便に評価でき, かつ視覚評価により類似した $\mathrm{HLH}$ 評価が可能であることがわかった。

そこで，頭髪画面上でいくつかの測定領域を設定し， それらの RGB 信号各々の平均輝度值を測定し, これら を $R, G, B$ value として以下の検討に用いた。

\section{1 頭髪表面の光反射特性観察および測定領域の決} 定

予備実験の結果から，視覚とより一致性の高い測定を 行ならためには, highlight 部と dark 部とを比較する ことであると考えられた。本研究ではとの部位，さらに は視覚がそれらをどのようにとらえているかを決定する ことが必要であった。

他方, カラーモニタ一画面上に映し出される頭髪画像 では，異なった反射を示寸幾つかの部位が観察された。 そこで，まずこれらの部位の反射光の特幑を非接触型色 彩計 (Minolta CS-100) 执よびゴニオフォメーターを 用いて明らかにした。

Fig.-2 は, model wig 頭髪のy 軸方向の明度と色の 変化を， L*a*b* 表色系で示したものである。画面上で 観察される highlight 部 ( $\mathrm{H}$ 部) は, 明度が高值を示す が色の影響は最も低い。しかし dark 部( D部) はこれ

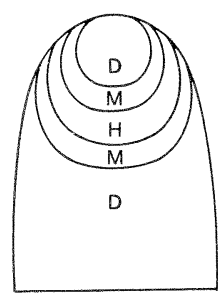

Fig.-2 Model schema of range of measurement. $\mathrm{H}, \mathrm{M}$ and $\mathrm{D}$ shows highlight portion, medium color. portion and dark portion, respectively. 
と逆の結果を示した。一方, 画面上で highlight 部に隣 接して観察されたやや明るい領域 $(M$ 部) は, 両者の中 間の性質を示した。

他方ゴニオフォトメーター測定により作成した頭髪の 反射分布曲線から, highlight 部に正反射光, その上部 に内部反射光, さらにその外部に拡散反射に上る表面反 射光の生ずることが示された。

これらの結果から, 頭髪からの光反射は以下の 3 種に 分類されることがわかった。

highlight 部（H部）; 正反射部。表面光沢色を発生

している。

中間色調部 (M部)； $\mathrm{H}$ 部と $\mathrm{D}$ 部の中間に出現する。

髮の色の特徴が正反射光の影響 で相殺されている。

dark 部 ( $\mathrm{D}$ 部) ; 拡散反射部。正反射光の影響は 小さく，髮の色の影響が支配的 である。

dark 部は，y軸方向の位置によって若干異なった性 質を示した。そこで dark 部は，M部に隣接した部位と そこから約80画素離れた部位とに分類した。予備実験の 結果から， dark 部の y 軸方向の長さは40画素に固定し た。 highlight 部はカラーモニタ一画面上で設定した。 また dark 部と $\mathrm{M}$ 部の境界は, $\mathrm{y}$ 軸方向の輝度変化や曲 線を測定し，そのピークカーブの延長線とベースライン の交点と定めた。

以上の如くして, 測定部位として頭髪画像の $\mathrm{H}$ 部， $M$ 部そしてD部をカラーモニタ一画面上で設定し, 各々の 領域の平均 $R, G, B$ value (以下 $R, G, B$ value) t求め た。そして、これらの測定值間の差和よび対比值等を計 算し、これらと視覚的つや值との相関を検索した。

\section{2 測定パラメーターの特定}

\subsection{1 明度を用いる方法の検索}

つやには，色の要素のうち明度が大きく関与している と考光ら机ている。そこで $\mathrm{R}, \mathrm{G}, \mathrm{B}$ value から, 次式を 用いて CIE- $(\mathrm{x} ・ \mathrm{y} ・ \mathrm{Y})$ 表色系の明度 $\mathrm{Y}$ を計算した1)。

$$
\mathrm{Y}=0.30 \mathrm{R}+0.59 \mathrm{G}+0.11 \mathrm{~B}
$$

このようにして求められた明度は, 物質の真の明度変 化と高い相関を示すことがわかった。とこで, 測定パラメ ーターとして明度Yを用いる方法でパネラー頭髮の HL $\mathrm{H}$ 評価を試みた。結果を Table-1 に示した。

その結果, highlight 部単独よりも, highlight 部と dark 部との明度の差, あるいはとの対比值が視覚的つ や値と高い相関を示した。

最も高い相関を示したのは, highlight 部とM部直下
Table-1 Correlation coefficients between the value of visual luster and calculated value from Lightness.

\begin{tabular}{lc}
\hline Calculated value & Coefficient \\
\hline Part H & 0.42 \\
Part H/Part M & 0.65 \\
Part H/Part D1 & 0.77 \\
Part H/Part D2 & 0.55 \\
Part H-Part D2 & 0.66 \\
\hline
\end{tabular}

Part D1 : Immediately below Part M.

Part D2 : 80 pixels below Part D1.

の dark 部との対比值を求めた時であり, その相関係数 は 0.77 であった。この方法で HLH の測定が可能であ ると考光ら机た。

3.2.2 R, G, B value を用いる方法の検討

髪のつや感には髪色が少なからず影響することが知ら れている1。従って,上述の方法に髪の色の影響を強調し て測定することにより，より視覚と一致性の高い HLH 評価が可能と考光られた。

そこで測定パラメーターとして，髮の色情報を含光》 $\mathrm{R}, \mathrm{G}, \mathrm{B}$ value を用いる方法についてさらに検討を加兄 た。

Table-2 飞 highlight 部とM部直下の dark 部の, $R, G, B$ value 間の対比值と, 視覚的つゃとの相関関係 を求めた結果の一例を示す。

今回の検討で視覚評価と最も高い相関を示したのは, highlight 部に B value, そしてM部直下の dark 部に $\mathrm{R}$ value を選び，その対比值，(Bh/Rd）を求めた時で 西り，その相関係数は 0.93 であった。

以上の検討結果から，HLH の測定パラィーターとし ては明度Yを用いる方法より， R, G, B value を用いる 方法が有用と考光た。

そして我々は, 本法から求められる物理的つや值（以 下 $\mathrm{Lph}$ をを以下のごとく定めた。

$$
\mathrm{Lph}=\mathrm{Bh} / \mathrm{Rd}
$$

この Lph を測定する客観的方法は，HLH の主観的 な視覚評洒代代替し得る方法であると考光られる。

Fig.-3に, blue 拈よび red color 画像と, 各々の 測定領域の例を示した。

\section{3 カラー画像解析法について}

つやを評価するとき，「経験のある観測者は，high一 light 部を周辺の暗い部分に対比しながらつやを観察す 
Table-2 Correlation coefficients between the value of visual luster and the contrast value of Part $\mathrm{H} /$ Part D1.

\begin{tabular}{clccc}
\hline & & \multicolumn{3}{c}{ Part H } \\
\cline { 3 - 5 } & & R value & G value & B value(Bh) \\
\hline \multirow{2}{*}{ Part D1 } & R value(Rd) & 0.84 & 0.82 & 0.93 \\
& G value & 0.68 & 0.74 & 0.82 \\
B value & 0.36 & 0.38 & 0.48 \\
\hline
\end{tabular}

Part $\mathrm{H}$ : Highlight portion

Part D1 : Dark portion immediately below Part M

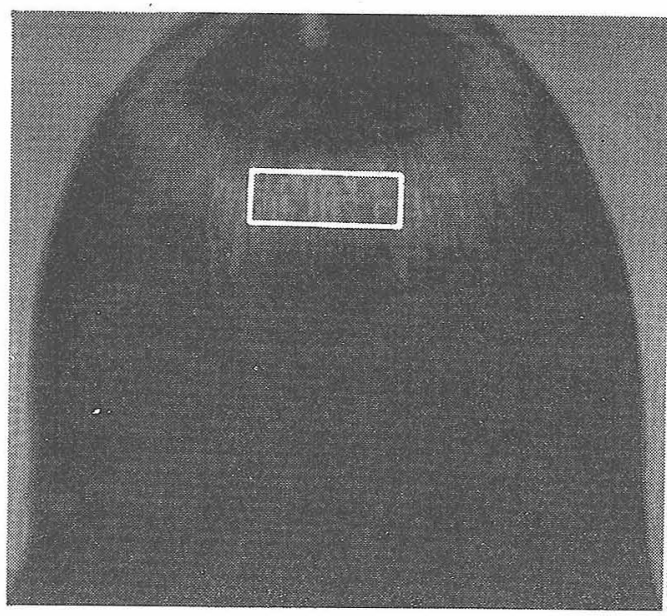

Blue color

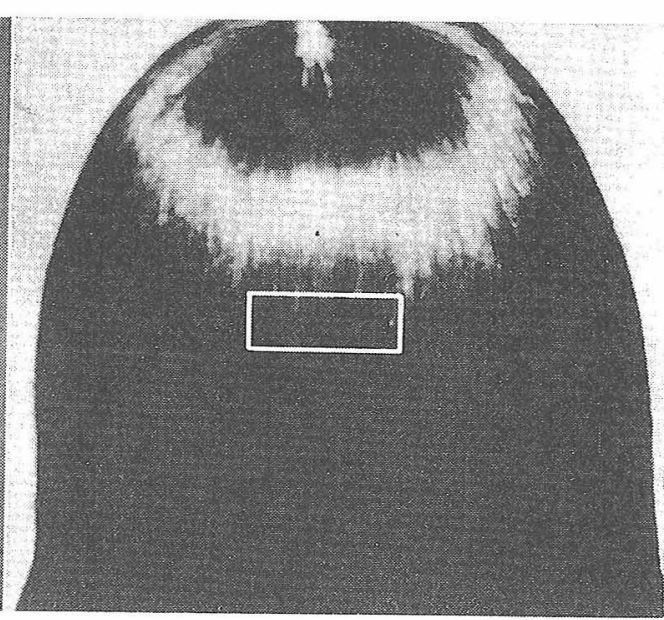

Red color

Fig.-3 Blue and Red color images and each measuring range of the scalp hair on color monitor screen.

る」と考えられている1。 今回の檢討結果では, highlight 部と M 部值下の dark 部の刘比值が視覚的つやと 最も良い、相関を示した。このことは，HLH が同じ様な 方法で観察されていること，そしてこれらの部位を比較 する我々の方法が妥当な方法であることを示している。 なた対比值を用いる今回の方法は, 光源や測定カメラの 波長特性の差や変化が相殺される結果, 分光補正を必要 としない8，といら大さなメリットがある。

今回定めた物理的つやすなわち Lph を測定すること により, 従来のゴニオフォトメーター法に比し, 視覚と 一致性の高いHLH 测定が可能であった。

その理由を明らかにする目的で，Lph㧧よびゴニオ オトメーター值がン゚ネラーの頭髮特性 9 項目（太さ，な めらかさ, 明るさ, 髮の量, 白髮, 枝毛, パサッキ感, 織維の並びの良し悪し, へアフライ）および機器測定項
目 (表面形態, 水分量, 静電気量, 測色值, くせっ毛 の出現頻度）とどのような関係を有するか調べた。そし て，各つや值が髮のどのよらな変化をとらえているわを 主因子分析, さらに重回帰分析により解析した。その結 果, Fig. -4 に示すごとく視覚的つや值は, キニーティ クルの状態が関与するミク口な表面变化因子, 绝変化因 子そして髪の配列状態が関与するマク口な状態変化因子. がその説明因子の上位を占めて和り，この3 因子が視覚 的つや值に大きく寄与していることがわかった。

一方, ゴニオフォトィーター值は頭髮状態のミクロな 表面変化因子と色変化因子の 2 因子のみをとら党, 視覚 的つや值の $22 \%$ 訲説明していないのに対し，Lphは視 覚的つや值と同様, ミク口表面変化因子, 色变化乞して マクロな状態変化の 3 因子をとらえており,かつ視覚的 つや值の $86 \%$ を説明していることがわかった。 


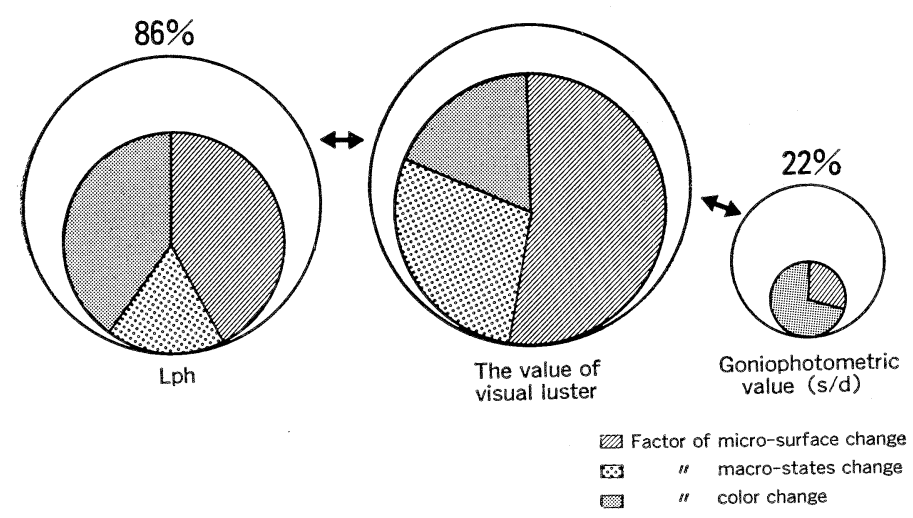

Fig. -4 The relationship between three values of measurement on hair characteristics. Explanatory factors (variables) of each value of measurement were determined by using factor analysis. The size of each factor repesents the degree of contribution calculated by using multi-regression analysis. The number $(\%)$ represents explanatory degree to the value of visual luster.

さらに，これら３要素を表面研磨，髪の配列攪乱とし て脱色などで変化させた毛束を用いたモデル実験でも， これらの 3 要素の変化にともなって L phは大きく変化す ること，として L phと視覚测定結果の間には良い一致性 の観察されることが示された。

またこのモデル実験に和いて，測定パラメーター Bh は，毛束の表面研磨，配列攪乱とともに大きく低下した ことからミクロな表面変化とマクロ状態変化が関係して いるパラメーターであり，一方 $\mathrm{Rd}$ は，毛束の脱色とと むに大きく上昇したことから色調変化が関係しているパ ラメーターであると考光られた。これらの結果は，従来 のゴニオフォトメーター法に比ベ，今回の方法を用いる ことにより HLH に関係するより多くの頭髪情報が得ら れることを示している。

他方, highlight 部と dark 部の 測定パラメーターに は，明度を選ぶより，各々に $\mathrm{B}$ value と $\mathrm{R}$ value を選 んだ時，視覚的つや值とより高い相関が示された。この ことは，HLH に髮色が少なからず影響していることを 示唆している。日本人の頭髪色は注とんどがマンセル表 色系の色相 YR 領域，すなわち黒色から黄赤色の色分布 を示す。この色分布が $\mathrm{B}$ value および $\mathrm{R}$ value の選ば れた事実と何らかの関係を有すると推察された。

この点をさらに検討する目的で, つやのある YR 色相 のマンセル色票を, 明度と彩度を変えて 7 枚用意し, こ れらの色票画像の $R, G, B$ value を測定した。その結果
Fig.-5 に示すごとく, 黑色から黄赤色への色変化を最 も大きな差としてとらえているのは R value であり， $\mathrm{B}$ value はこの色変化をほとんどとらえていないことが わかった。このことは，色の影響が支配的である頭髮画 像の dark 部に拈いても, その色変化を最も鋭敏にとら えるのが R value であることを示している。

一方, highlight 部には, 頭髮からの正反射部分のみ ならず一部に拡散反射部分も混在しているが，視覚評価 ではこの正反射部分のみが強く知覚される。カラ一画像 処理法ではこれら 2 つ反射部分が測定される。このこ とは, highlight 部の $R, G, B$ value の比がパネラー間

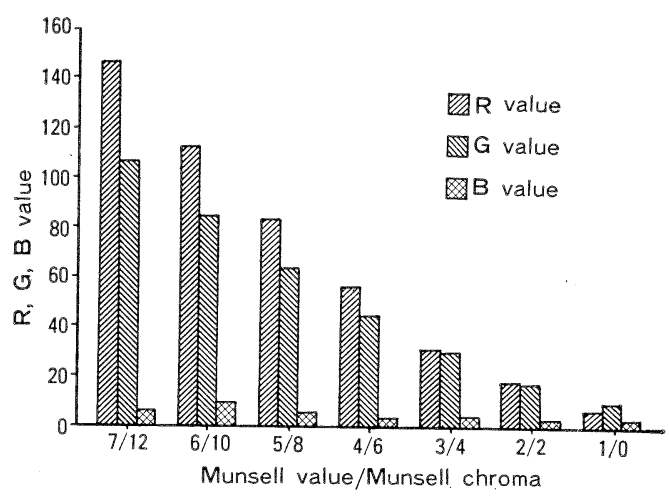

Fig.-5 R, G, B value of Munsell color tips in Munsell Hue $10 \mathrm{YR}$ (yellowish red). 
で異なって扣り, highlight 部にも色の影響が出てい だ)ことからも明らかであった。B value はこの highlight 部に瀮出する黄赤色の影響, そして扣そらく光源 色の影響も消去して，より視覚に近い測定データを提供 していると思われる。

以上のごとく, Bh そして Rd は HLH に対する髪色 の影響を最も正確にとらえていると考えられる。

\section{4 ヘアケア製品の有用性検索への利用}

今回開発したカラー画像処理法は, ヘアケア製品の影 響や効果測定にも利用可能であった。以下，その実施例 のいくつかを示す。

\subsection{1 染毛の影響}

HLH に対する頭髪着色の効果を明らかにする目的で， ブリーチで脱色した毛束を市販染染毛剂を用いて 4 色に 染毛した。Fig.-6 はその時の Lph の変化を示す。

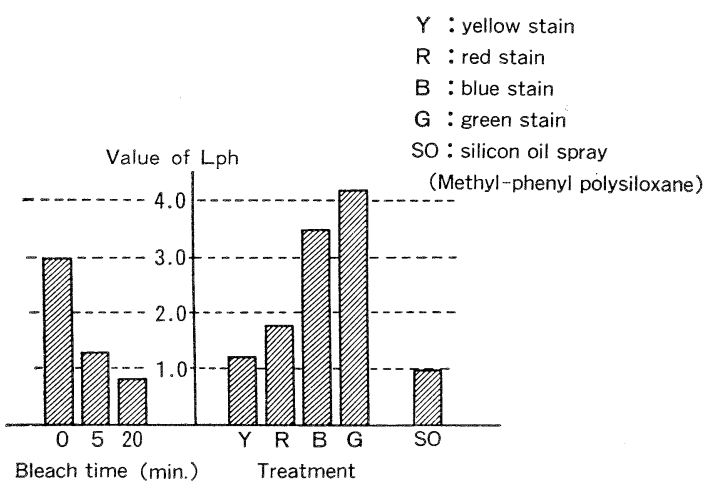

Fig.-6 Effect of bleaching on hair luster and effect of dying and oil spraying on the luster of bleached hair ( $20 \mathrm{~min}$.). Specimens; hair bundles $(n=3)$.

観察した 4 色のなかでは特に青と緑染色が高いL L p 上 昇効果を示した。これは黄, 赤染色に比し, 青, 緑染色 のはらが髪の明度をより強く低下するためと考えられ る。またブリーチ脱色毛には，つや出し油剤をスプレー するよりも着色するほらが $\mathrm{Lph}$ 上昇効果は大きいことが わかった。

他方，ブリーチ前の黒毛に青染色を行った結果，青緑 染色の程度が強まる程 L ph も高くなる傾向を示し, 最大 で染色前の 1.26 倍の上昇が観察された。ゴニオフォトメ 一ター法ではこの上昇は観察されなかった。この観察結 果は, いままで一部の人によって「黒髪を青染色すると 鬞のつやは増加してみえる」と経験的に感じられてきた
ことが，事実であることを裏付けている。

3.4.2 つや出し剂の効果

Fig.-7 は，当社へアケア製品 4 品とそれらに用いら。 れている油剤の効果を, 毛束を用いて観察した結果であ, る。

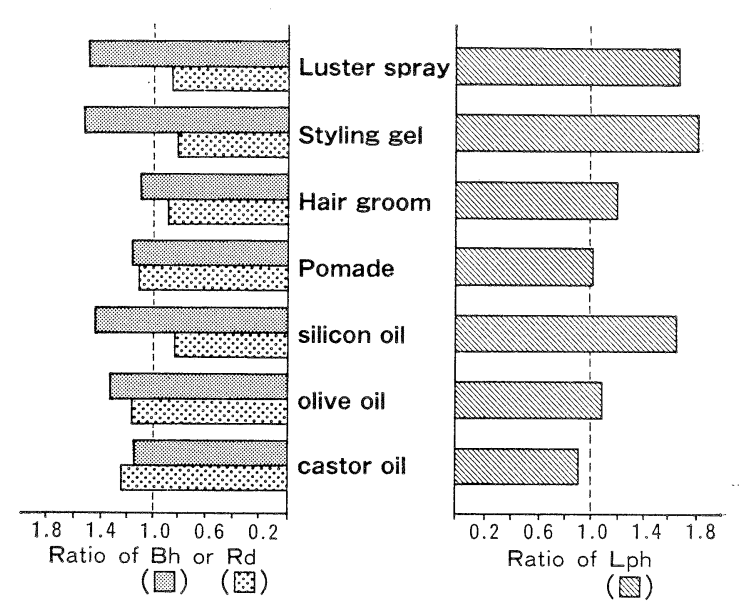

Fig.-7 Effect of lustering preperations and oils on hair luster. The value under the abscissa indicates the ratio of afterversus before-treatment. Silicon oil; Methyl-phenyl-polysiloxane.

Specimens; hair bundle $(n=3)$.

ラスタースプレーとスタイリングジェルには，高いつ や出し効果が観察された。これは, シリコン油が highlight 部の正反射を増加する効果, および髪繊維内部に 浸透し dark 部の拡散反射を低下する効果により説明さ れる。

一方これらに比し, ヘアグルームやポマードのつや出 し効果は低かった。特にポマード塗布により，ゴニオフ オトメーター值は約 5 倍の上昇を示したが, Lph は変化 を示さなかった。視覚観察結果は， Lph 測定結果を支持 していた。このポマードのつや出し効果の欠如は, 用い られた油剤, 即ち caster oil が dark 部の拡散反射を 増加したことにより説明される。

他方パネラーを用いた検討で，ラスタースプレーを頭 髮に塗布しても $\mathrm{Lph}$ 上昇効果の観察されないパネラーが 存在した。これらのパネラーは, 特にくせ毛の多いこと が特徴であった。 dark 部の拡散反射を増大させる油剤. 
がつや出し効果を持たないこと，〈せ毛の多い頭髪には シリコーン油などのつや出し油剤の効果が出にくいこと がわかった。

3.4.3 コンディショナーの効果

Fig.-8は，洗浄前後に打ける頭髪つやの変化を model wig を用いて測定した結果である。

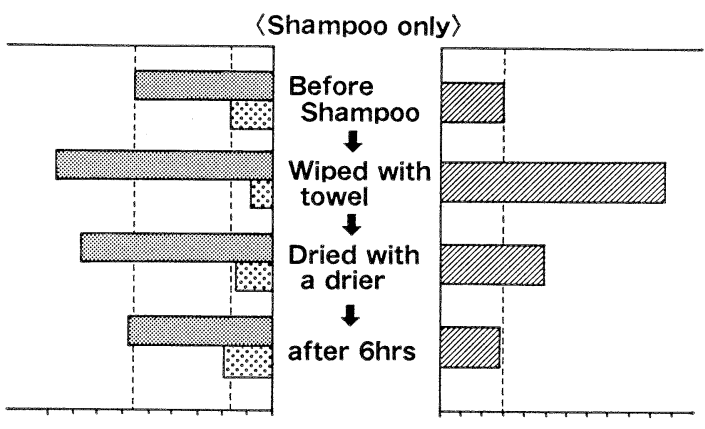

〈Shampoo+ Conditioner

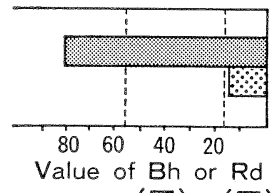

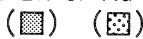

\section{after $6 \mathrm{hrs}$}

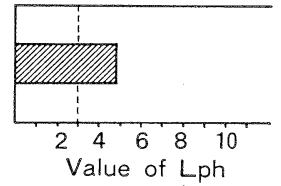

(『)
Fig.-8 Effect of shampoo and conditioner on hair luster. "After 6 hrs." in<Shampoo + Conditioner $>$ shows the change after wiping with towl and drying with a drier of same way as $\langle$ Shampoo only $\rangle$. Specimens; Model wig.

シャンプー後の需れた髪では, highlight 部の強い正 反射と dark 部の明度低下が視覚的に観察される。しか し髪が乾燥するに従い highlight 部の正反射は低下し, dark 部の明度や髪の配列もシャンプー前の状態に戻る。 $\mathrm{Lph}$ そして Bh, Rdの変化は，このような頭髮の状態変 化を良く再現していた。

またシャンプー単独の時に比べ，コンディショナーの 併用は, highlight 部の正反射増加と dark 部の 拡散反 射低下作用により L ph の上昇をもたらした。コンディ ショナーの L ph 上昇効果はパネラーを用いた検討でも 認められ，Fig。-9に示すように，特に髮の配列の悪い パネラーで顕著な効果を示すことがわかった。

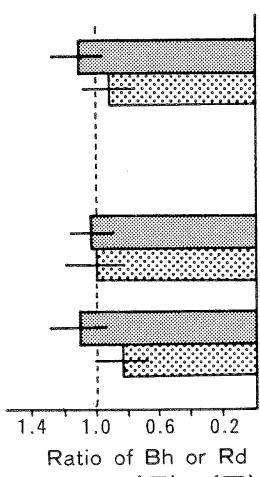

(미) (B)

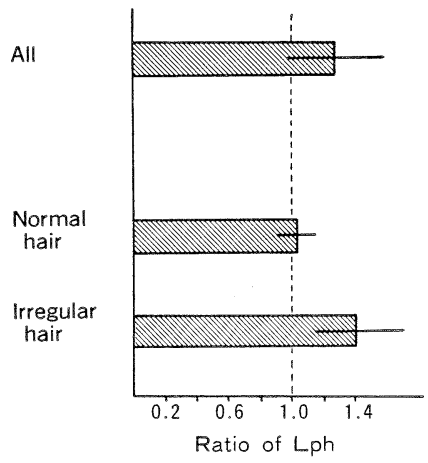

(田)
Fig.-9 Effect of conditioner following shampoo on the luster of different conditions of panel head hair (All: $n=15$ ). The value of under the abscissa indicates the ratio of after-(the use of shampoo + conditioner) versus after-(the use of shampoo only).

このようなコンディショナーのつや出し効果は, 髪の 柔軟化によるマクロ状態改善効果によるものと考光られ る。従って，〈せ毛等の問題を有する人達のつやの悩み 改善には，コンディショナーによるマクロ状態改善のア ドバイスがなされるべきであると考劣る。

\section{4. 総 括}

頭髪つやの主観的な視覚評価に代替しらる機器測定法 として, カラー画像解析法を開発した。本法を用いるこ とにより, 従来のゴニオフォトメーター法に比し, 正確 な頭髪つやの測定が可能である。

本法を用いて，頭髮製品のつや出し効果を検索した。 また，今まで視覚的あるいは従来法では困難であったい。 くつかの測定が，我々の方法を用いることにより可能で あることを示した。

頭髪つやには, 頭髪状態に関する多くの要素が関係し ている。従って, 今回開発した方法は, 頭髪の健康状態 や頭髪製品の有効性について更に多くの情報を得るため に使用でさると考光られる。

謝辞 本研究に有益な御助言を頂いた元熊本大学相田 貞蔵教授に深謝します。 


\section{文 献}

1）色彩科学協会編, “色彩科学ハンドブック” p. 391 (1962)

2) R.S.Hunter, Res. Nat. Strand., 18 (1937)

3) 蓮沼 宏, “光沢” p. 81 (1960) コロナ社

4) S. Serikawa, T.Aida, Trans. IECE Japan, E69, 589 (1986)
5) 芹川聖一, 相田貞蔵, 熊本大学工学部研究報告, 38, 263 (1989)

6) 舟久保登, 電学論 D, 68, 949 (1985)

7) 佐藤 元, 都築泰広, 宮坂祥夫, 吉野峰生, 三宅 文太郎，瀬田季茂，科警研報告，40，187（1987）

8）相田貞蔵, 嶋田豊秋, 小鉢光夫, 芹川聖一, 釘澤 秀夫, 内村圭一, 電学論 C, 109, 67 (1989)

(1991年 3 月29日受理) 